\title{
CHANGES IN THE HARDWOOD GROVES OF THE MARTONVÁSÁR MANOR PARK (HUNGARY) IN THE LAST 30 YEARS
}

\author{
B. KeveY ${ }^{1}$, I. Majláth ${ }^{2}$ and M. MolnáR ${ }^{3}$ \\ ${ }^{1}$ Department of Ecology, University of Pécs \\ H-7624 Pécs, Ifjúság u. 6, Hungary; E-mail: keveyb@gamma.ttk.pte.hu \\ ${ }^{2}$ Centre for Agricultural Research, Hungarian Academy of Sciences \\ H-2462 Martonvásár, Brunszvik utca 2, Hungary; E-mail: majlath.imre@agrar.mta.hu \\ ${ }^{3}$ H-2462 Martonvásár, Brunszvik utca 2, Hungary; E-mail: marci1985@gmail.com
}

(Received 1 August, 2016; Accepted 15 August, 2016)

\begin{abstract}
The subject of the present study is the monitoring of the hardwood groves at the Martonvásár Manor Park with the involvement of 20 earlier (recorded in 1980-1981) and 20 current (recorded in 2011-2012) phytocoenological relevés. The manor park was created in the first half of the 19th century. Since then the woods along the St László stream have developed into species-rich and semi-natural forests, which can be identified as related to the oak-ash-elm groves (Scillo vindobonensis-Ulmetum) of the Zámoly Basin and the Csepel Island. The results of the current monitoring repeated 30 years after the first survey show momentous changes in forest dynamics such as the ageing-related opening of the upper canopy and an intense closure of the lower canopy and shrub layer. The ratio of the invasive species doubled. Present findings may provide additional information for long-term forest ecology research, however, results could be considered as changes of a semi-natural hardwood forest with minimal human impact.
\end{abstract}

Key words: invasive species, LTER, manor park, Scillo vindobonensis-Ulmetum, semi-natural habitat

\section{INTRODUCTION}

In Europe, several long-term ecological research (LTER) sites have been established. One of these LTER sites can be found in Hungary at the forest of Síkfókút (Jakucs 1973). Besides natural forests, the study of vegetation at manor parks and botanical gardens may offer interesting findings in spite of the obvious human disturbance on them. There is no sufficient information about how man-made forest vegetation changes along a stream, which can be regarded as an ecological corridor. 
In Europe, complex monitoring had been developed at numerous manor parks for adequate management (e.g. Knepp Castle, West Grinstead, UK). Several sources in the Hungarian literature are known, which present important data on the flora of several manor parks in the former and present territory of Hungary. One of the early studies on the flora and vegetation at the Zichy Manor Park at Nagyláng (now: Soponya), Transdanubian Region showed that distinguishing the native and introduced species is quite problematic (Hangay 1889 ).

Early renowned botanists of Hungary have already found the Martonvásár Manor Park remarkable for its natural-like groves. Ádám Boros mentioned several interesting plants in his 1933 travel diary (e.g. Allium ursinum, Arum orientale (known as A. maculatum at that time), Helleborus dumetorum), and he recorded that there were "semi-wild areas at the lakeside", which were "natural wood-like at some places" although "the plants were likely to have been partly acclimated" (cf. Kevey 1987). In 1954, Sándor Jávorka collected Allium ursinum from the park and handed it over to the Herbarium of the Hungarian Natural History Museum (cf. Kevey 1979). In 1974, Adolf Olivér Horváth visited the park with one of his students (cf. Manninger 1989). The park itself has survived in relatively good condition. It was designed by Christian Heinrich Nebbien, one of the best landscape architect of his age. Natural forest fragments have formed thanks to the English style. According to the original concept of the English garden, the park merged unnoticeably into the local landscape without distinct boundary or fences. This idea has been prevailing in Martonvásár, too. The guiding principle was to build a park that reflects the characteristics of the climate, landscape and vegetation. It could be created only by taking the local vegetation into account. Thus, its final look shows as if it was naturally formed and does not reveal any violence carried out on the environment (Pückler 1834 in Ormos 1967, Zádor 1973). In 1945 , the park lost $70 \%$ of its territory. The area was divided and managed by forestry. However, the remaining 70 ha territory still shows the characteristics of the English garden.

The first botanical monitoring at the Martonvásár Manor Park was carried out in 1980-1981 when more than 30 coenological relevés were taken in the woods (mainly in oak-ash-elm groves, secondarily in alder groves and hornbeam- and oak-woods) of the park. The study with the title of "The oakash-elm groves of the Martonvásár Manor Park" (Kevey 1987) was prepared based on 15 selected relevés of the 30 original ones. The records were analysed and described in synthetic tables. After 30 years, the authors took the relevés at the same places, thus making it possible to reveal the changes in these habitats. The coenotaxonomic status of the studied grove was also determined. 


\section{MATERIALS AND METHODS}

\section{Characterisation of the research area}

The research area is located at the northeastern territory of the Brunszvik Manor Park that lays mainly at the alluvial bottom of the St László stream valley and secondarily on the terraces of the stream, which are covered by muddy, loessy and sandy fluvial alluvium. This alluvium consists of nut sized quartz, limestone (originating from the Gerecse Mts) and dolomite pebbles (Âdám et al. 1959). On the pebbly alluvium, poured forest soil mixed with loess was formed. Intense water management was carried out during the shaping of the manor park in the 19th century. During this process, the stream and its fork, which feeds the lake and flows back to the main branch through the Malom-árok (Mill ditch), were controlled by embankments. In the middle of the artificial lake, the implementer created an island and drained the marshes along the stream. These works only slightly affected the forest areas, therefore, the St László stream still has an advantageous effect on the microclimate and provides optimal growth conditions for the hardwood groves. In years with plenty of precipitation (e.g. 1996, 2010), mainly in spring, the lower areas were flooded for even 1 month. There is a gradient in the vegetation according to the microrelief and soil water level. The water regime of the St László stream is considerably erratic. Its water yield mainly comes from rainfalls and an 8000-fold difference between its highest and lowest water yield can be observed (Ádám et al. 1959).

According to the forest climate typology, the climate of the study area can be described as forest steppe showing strong continental characteristics. Its average annual temperature is $10.5^{\circ} \mathrm{C}$. Extreme values such as $-32.1^{\circ} \mathrm{C}$ (January 1942) and $37.4^{\circ} \mathrm{C}$ (August 1972) were observed. The stream valley location favours long periods with subzero temperature conditions. The average annual precipitation is $550 \mathrm{~mm}$, which has a maximum in the summer. In recent years, a second maximum was observed in the winter due to the intensification of the sub-Mediterranean influence. Recently, there were intense fluctuations observed in rainfall (maximum: 2010 (1014 mm), minimum: 2011 $(296 \mathrm{~mm}))$.

\section{Applied methods}

The coenological relevés were taken according to the traditional quadrat method of the Zürich-Montpellier Plant Coenological School (Becking 1957, Braun-Blanquet 1964). "NS" computer software package was used to compile the records in tables and calculate the percentage of character species of dif- 
ferent syntaxa based on $\mathrm{K} \%$ (Ch-K) and A-D\% (Ch-AD) (Kevey and Hirmann 2002). The methods of recording and the slightly modified method of the traditional statistical calculations were published by Kevey (2008). Identifying the nativity of species emerged as a problem during the analysis. Therefore, to calculate the ratio of character species, we chose the following solution: those species that were found to be native elsewhere in Hungary were not classified as adventive species even if it was sure that they came to the manor park through introduction or they might have been planted.

Phytocoenological relevés originating from two relatively close area were investigated to elucidate the similarity of the association Scillo vindobonensis-Ulmetum in different localities (10 relevés in Zámoly Basin (Kevey ined.); 25 relevés in Csepel Island (Kevey ined.)). Binary cluster analysis (method: complete link, coefficient: Baroni-Urbani and Buser) and ordination (method: principal coordinates analysis, coefficient: Baroni-Urbani and Buser) were carried out using the Syn-Tax 2000 program (Podani 2001).

In case of the species, we used the nomenclature of Király (2009), and in case of communities the nomenclature of Borhidi and Kevey (1996), Kevey (2008) and Borhidi et al. (2012) was used. The structure of the phytocoenological relevés was based on the modified coenological system (Oberdorfer 1992, Mucina et al. 1993, Borhidi et al. 2012, Kevey 2008) of Soó (1980). By the coenosystematical classification of the plants, also Soó's Synopsis (1964, 1966, 1968, 1970, 1973, 1980) was used but more recent researches were also taken into account (cf. Borhidi 1993, 1995, Horváth et al. 1995, Kevey ined.).

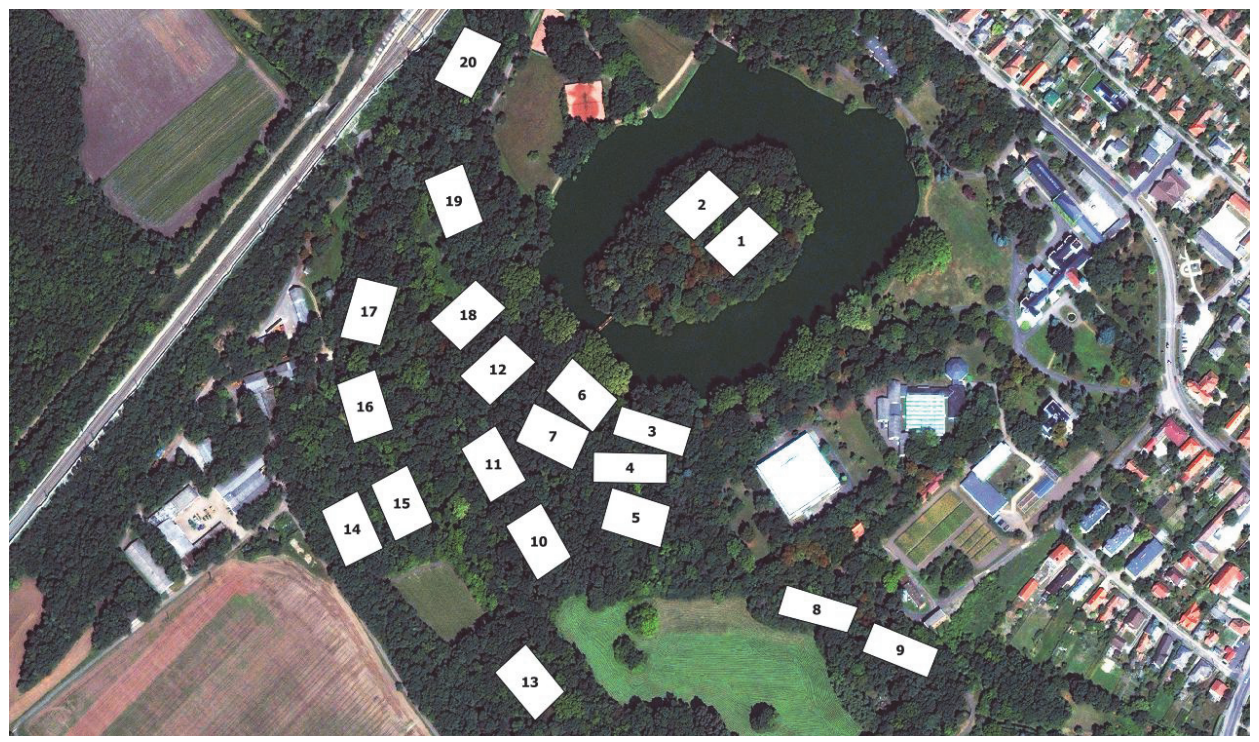

Fig. 1. Location of the quadrates in the study area 
Digitalisation of the paper map of the quadrates from 1981 was carried out using the Quantum GIS 2.2.0 (Valmiera) open source GIS software (QGIS 2014) (Fig. 1, Table S1).

The results were the means of the relevés and were statistically evaluated using the standard deviation and T-test methods (see Tables S1, S2 and S3).

\section{Abbreviations}

A1 = upper canopy, A2 = lower canopy, Agi = Alnenion glutinosae-incanae, $\mathrm{Ai}=$ Alnion incanae, $\mathrm{Apa}=$ Abieti-Piceea, $\mathrm{AQ}=$ Aceri tatarici-Quercion, $\mathrm{AR}=$ Agropyro-Rumicion crispi, $\mathrm{Ar}=$ Artemisietea, $\mathrm{Ara}=$ Arrhenatheretea, Ate $=$ Alnetea glutinosae, B1 = shrub layer, B2 = lower shrub layer (saplings), Bia = Bidentetea, $\mathrm{C}=$ herb layer, $\mathrm{Cal}=$ Calystegion sepium, $\mathrm{Che}=$ Chenopodietea, $\mathrm{ChS}=$ Chenopodio-Scleranthea, $\mathrm{Ch}-\mathrm{AD}=$ percentage of characteristic species of different syntaxa based on A-D\% ("csoporttömeg" in Hung.), Ch-K = percentage of characteristic species of different syntaxa based on $\mathrm{K} \%$ ("csoportrészesedés" in Hung.), $\mathrm{Cp}=$ Carpinenion betuli, $\mathrm{D}=$ dominance classes on a discrete scale of 1-5, Epa $=$ Epilobietea angustifolii, $\mathrm{EuF}=$ Eu-Fagenion, ex verb. $=$ ex verbis (oral statement), $\mathrm{F}=$ Fagetalia sylvaticae, $\mathrm{FBt}=$ Festuco-Brometea, $\mathrm{FPi}=$ Festuco-Puccinellietalia, $\mathrm{GA}=$ Galio-Alliarion, ined. $=$ ineditum (inedited), $\mathrm{K}=$ constancy classes on a discrete scale of $\mathrm{I}-\mathrm{V}$, Mag = Magnocaricetalia, $\mathrm{MoA}=$ Molinio-Arrhenatherea, $\mathrm{MoJ}=$ Molinio-Juncetea, $\mathrm{OCn}=$ OrnoCotinion, $\mathrm{Pla}=$ Plantaginetea, $\mathrm{Pna}=$ Populenion nigro-albae, $\mathrm{Pol}=$ Polygonion avicularis, $\mathrm{PQ}=$ Pino-Quercetalia, $\mathrm{Prf}=$ Prunion fruticosae, Pru $=$ Prunetalia spinosae, $\mathrm{Pte}=$ Phragmitetea, $\mathrm{Qc}=$ Quercetalia cerridis, $\mathrm{Qfa}=$ Quercion farnetto, $\mathrm{QFt}=$ Querco-Fagetea, $\mathrm{Qpp}=$ Quercetea pubescentis-petraeae, $\mathrm{Qr}=$ Quercetalia roboris, $\mathrm{Qrp}=$ Quercion robori-petraeae, $\mathrm{S}=$ summa (sum), Sal = Salicion albae, SBT = social behaviour types, Sea $=$ Secalietea, $\mathrm{s} .1$. = sensu lato (in wider sense), $\mathrm{Spu}=$ Salicetea purpureae, $\mathrm{TA}=$ Tilio platyphyllae-Acerenion pseudoplatani, Ulm $=$ Ulmenion, US $=$ Urtico-Sambucetea, VP = VaccinioPiceetea.

\section{RESULTS}

As the coenological characterisation of the oak-ash-elm groves of Martonvásár can be read in the study of Kevey (1987), we would like to draw the attention only to the changes occurred during the past three decades (cf. Tables S2-S3 and Tables 1-2). 
Table 1

Changes in the ratio of the syntaxa $(\mathrm{Ch}-\mathrm{K}=$ percentage of characteristic species of different syntaxa based on $\mathrm{K} \%, \mathrm{Ch}-\mathrm{AD}$ = percentage of characteristic species of different syntaxa based on A-D\%)

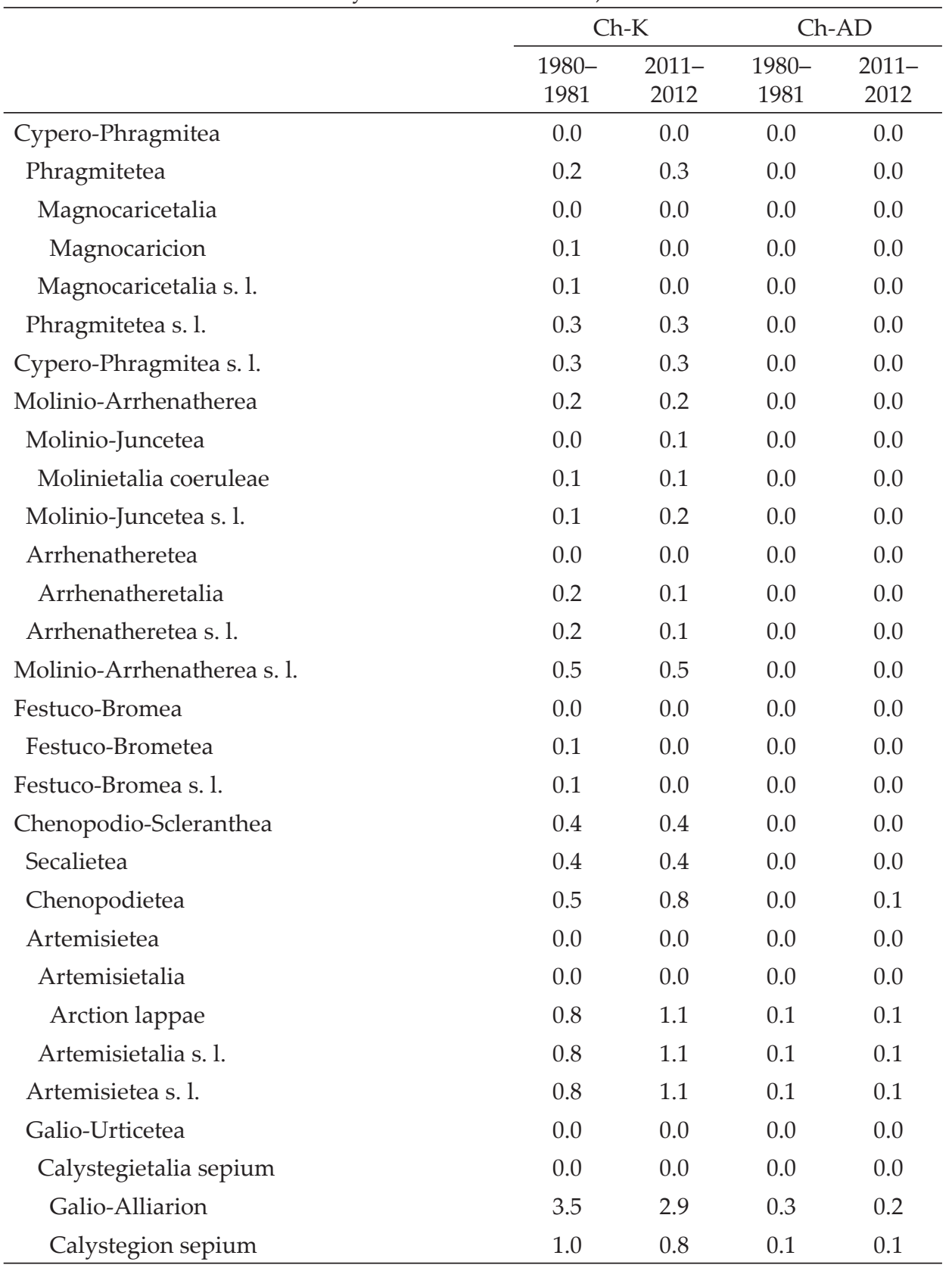


Table 1 (continued)

\begin{tabular}{|c|c|c|c|c|}
\hline & \multicolumn{2}{|c|}{ Ch-K } & \multicolumn{2}{|c|}{ Ch-AD } \\
\hline & $\begin{array}{c}1980- \\
1981\end{array}$ & $\begin{array}{c}2011- \\
2012\end{array}$ & $\begin{array}{c}1980- \\
1981\end{array}$ & $\begin{array}{c}2011- \\
2012\end{array}$ \\
\hline Galio-Urticetea s. 1. & 4.5 & 3.7 & 0.4 & 0.3 \\
\hline Bidentetea & 0.0 & 0.0 & 0.0 & 0.0 \\
\hline Bidentetalia & 0.0 & 0.1 & 0.0 & 0.0 \\
\hline Bidentetea s. 1. & 0.0 & 0.1 & 0.0 & 0.0 \\
\hline Plantaginetea & 0.0 & 0.0 & 0.0 & 0.0 \\
\hline Plantaginetalia majoris & 0.1 & 0.1 & 0.0 & 0.0 \\
\hline Plantaginetea s. 1. & 0.1 & 0.1 & 0.0 & 0.0 \\
\hline Epilobietea angustifolii & 0.0 & 0.0 & 0.0 & 0.0 \\
\hline Epilobietalia & 5.1 & 5.2 & 1.1 & 1.8 \\
\hline Epilobietea angustifolii s. 1. & 5.1 & 5.2 & 1.1 & 1.8 \\
\hline Urtico-Sambucetea & 0.0 & 0.0 & 0.0 & 0.0 \\
\hline Sambucetalia & 0.0 & 0.0 & 0.0 & 0.0 \\
\hline Sambuco-Salicion capreae & 0.5 & 0.5 & 0.5 & 1.2 \\
\hline Sambucetalia s. 1. & 0.5 & 0.5 & 0.5 & 1.2 \\
\hline Urtico-Sambucetea s. 1. & 0.5 & 0.5 & 0.5 & 1.2 \\
\hline Chenopodio-Scleranthea s. 1. & 12.3 & 12.3 & 2.1 & 3.5 \\
\hline Querco-Fagea & 0.0 & 0.0 & 0.0 & 0.0 \\
\hline Salicetea purpureae & 0.0 & 0.0 & 0.0 & 0.0 \\
\hline Salicetalia purpureae & 1.7 & 1.8 & 0.3 & 0.2 \\
\hline Salicion albae & 1.0 & 0.6 & 0.3 & 0.1 \\
\hline Populenion nigro-albae & 0.9 & 0.8 & 0.1 & 0.1 \\
\hline Salicion albae s. 1 . & 1.9 & 1.4 & 0.4 & 0.2 \\
\hline Salicetalia purpureae s. 1 . & 3.6 & 3.2 & 0.7 & 0.4 \\
\hline Salicetea purpureae s. 1. & 3.6 & 3.2 & 0.7 & 0.4 \\
\hline Alnetea glutinosae & 0.0 & 0.0 & 0.0 & 0.0 \\
\hline Alnetalia glutinosae & 2.2 & 1.9 & 7.3 & 6.7 \\
\hline Alnetea glutinosae s. 1 . & 2.2 & 1.9 & 7.3 & 6.7 \\
\hline Querco-Fagetea & 19.3 & 17.8 & 14.2 & 11.7 \\
\hline Fagetalia sylvaticae & 18.7 & 16.2 & 36.6 & 39.2 \\
\hline Alnion incanae & 8.1 & 7.3 & 16.6 & 15.5 \\
\hline Alnenion glutinosae-incanae & 0.4 & 0.4 & 0.1 & 0.1 \\
\hline Ulmenion & 1.2 & 0.8 & 1.1 & 0.6 \\
\hline
\end{tabular}


Table 1 (continued)

\begin{tabular}{|c|c|c|c|c|}
\hline & \multicolumn{2}{|c|}{ Ch-K } & \multicolumn{2}{|c|}{ Ch-AD } \\
\hline & $\begin{array}{c}1980- \\
1981\end{array}$ & $\begin{array}{c}2011- \\
2012\end{array}$ & $\begin{array}{c}1980- \\
1981\end{array}$ & $\begin{array}{c}2011- \\
2012\end{array}$ \\
\hline Fagion sylvaticae & 0.0 & 0.0 & 0.0 & 0.0 \\
\hline Eu-Fagenion & 0.3 & 0.3 & 0.1 & 0.1 \\
\hline Carpinenion betuli & 3.4 & 3.5 & 3.6 & 2.9 \\
\hline Tilio platyphylli-Acerenion pseudoplatani & 4.6 & 4.3 & 4.1 & 4.3 \\
\hline Cephalanthero-Fagenion & 0.0 & 0.1 & 0.1 & 0.1 \\
\hline Fagion sylvaticae s. 1 . & 8.3 & 8.2 & 7.9 & 7.4 \\
\hline Aremonio-Fagion & 0.1 & 0.3 & 0.0 & 0.1 \\
\hline Fagetalia sylvaticae s. 1 . & 36.8 & 33.2 & 62.3 & 62.9 \\
\hline Quercetalia roboris & 0.0 & 0.2 & 0.0 & 0.0 \\
\hline Querco-Fagetea s. 1. & 56.1 & 51.2 & 76.5 & 74.6 \\
\hline Quercetea pubescentis-petraeae & 12.4 & 11.2 & 9.1 & 8.2 \\
\hline Orno-Cotinetalia & 0.0 & 0.0 & 0.0 & 0.0 \\
\hline Orno-Cotinion & 0.1 & 0.1 & 0.1 & 0.1 \\
\hline Orno-Cotinetalia s. 1. & 0.1 & 0.1 & 0.1 & 0.1 \\
\hline Quercetalia cerridis & 0.1 & 0.0 & 0.0 & 0.0 \\
\hline Quercion farnetto & 0.1 & 0.2 & 0.0 & 0.1 \\
\hline Aceri tatarici-Quercion & 0.3 & 0.3 & 0.2 & 0.0 \\
\hline Quercetalia cerridis s. 1. & 0.5 & 0.5 & 0.2 & 0.1 \\
\hline Prunetalia spinosae & 0.4 & 0.4 & 0.0 & 0.0 \\
\hline Prunion fruticosae & 0.2 & 0.2 & 0.0 & 0.0 \\
\hline Prunetalia spinosae s. 1. & 0.6 & 0.6 & 0.0 & 0.0 \\
\hline Quercetea pubescentis-petraeae s. 1. & 13.6 & 12.4 & 9.4 & 8.4 \\
\hline Querco-Fagea s. 1. & 75.5 & 68.7 & 93.9 & 90.1 \\
\hline Abieti-Piceea & 0.0 & 0.0 & 0.0 & 0.0 \\
\hline Vaccinio-Piceetea & 0.0 & 0.0 & 0.0 & 0.0 \\
\hline Pino-Quercetalia & 0.0 & 0.0 & 0.0 & 0.0 \\
\hline Pino-Quercion & 0.0 & 0.1 & 0.0 & 0.0 \\
\hline Pino-Quercetalia s. 1. & 0.0 & 0.1 & 0.0 & 0.0 \\
\hline Vaccinio-Piceetea s. 1. & 0.0 & 0.1 & 0.0 & 0.0 \\
\hline Abieti-Piceea s. 1. & 0.0 & 0.1 & 0.0 & 0.0 \\
\hline Indifferent & 2.5 & 2.8 & 0.7 & 1.3 \\
\hline Adventive & 8.5 & 14.9 & 3.0 & 5.1 \\
\hline
\end{tabular}


Table 2

Changes in the ratio of social behaviour types (SBT) (Ch-K: percentage of characteristic species of different syntaxa based on $\mathrm{K} \%$, Ch-AD: percentage of characteristic species of different syntaxa based on A-D\%).

\begin{tabular}{lrrrrr}
\hline SBT & & \multicolumn{2}{c}{ Ch-K } & \multicolumn{2}{c}{ Ch-AD } \\
\cline { 3 - 6 } & & $1980-1981$ & $2011-2012$ & $1980-1981$ & $2011-2012$ \\
\hline S & 6 & 7.1 & 6.7 & 7.0 & 8.7 \\
Su & 10 & 0.8 & 0.8 & 1.0 & 0.3 \\
Sr & 8 & 0.0 & 0.0 & 0.0 & 0.0 \\
C & 5 & 14.9 & 16.1 & 39.9 & 34.5 \\
Cu & 9 & 0.0 & 0.0 & 0.0 & 0.0 \\
Cr & 7 & 0.0 & 0.0 & 0.0 & 0.0 \\
G & 4 & 43.9 & 36.8 & 44.7 & 45.0 \\
Gu & 8 & 0.0 & 0.0 & 0.0 & 0.0 \\
Gr & 6 & 0.0 & 0.0 & 0.0 & 0.0 \\
NP & 3 & 0.0 & 0.0 & 0.0 & 0.0 \\
DT & 2 & 20.3 & 19.3 & 4.0 & 5.9 \\
W & 1 & 4.3 & 5.2 & 0.4 & 0.4 \\
I & -1 & 5.1 & 8.6 & 1.6 & 2.5 \\
A & -1 & 0.4 & 0.9 & 0.0 & 0.1 \\
RC & -2 & 0.1 & 0.3 & 0.0 & 0.0 \\
AC & -3 & 3.2 & 5.4 & 1.4 & 2.5 \\
Val & & 3.3 & 2.9 & 4.3 & 4.1 \\
\hline & & & & &
\end{tabular}

\section{Physiognomy}

Compared to the survey made in 1980-1981, the trees proved to be higher both in the upper (A1) and lower canopy (A2). The average trunk diameter also increased. The coverage of the A1 decreased in most of the studied areas. In contrast to this, the coverage of the $\mathrm{A} 2$ increased in the quadrates in general. There was negligible change in the constancy $(\mathrm{K}$, discrete scales $\mathrm{I}-\mathrm{V})$ of the canopy's elements. Their A-D class (D, discrete scale $1-5)$ value also increased with one grade only. Thus, in A2 level, the coverage of Acer campestre increased from 2 to 3 in several quadrates and the D value of Acer platanoides from 1 to 2 .

Both the height and the D value of the shrub layer (B1) became larger. Mainly the shrub-sized specimens of trees proliferated but their K and D values changed only with 1 grade. The exception is Viburnum opulus: its K de- 
creased with 2 grades. Furthermore, in certain quadrates, the D of Padus avium and Staphylea pinnata increased from 3 to 4 and from 2 to 3, respectively. The $\mathrm{D}$ value of the lower (B2) shrub layer also increased in most cases. The $\mathrm{K}$ of Viburnum opulus also decreased with 2 grades in this level. The most striking finding is the spreading of Hedera helix. In some of the quadrates, its D increased from 1 to 4 and from 2 to 5 .

At some places, the $\mathrm{D}$ value of the herb layer (C) did not change, while it increased at other places. In general, their $\mathrm{K}$ and $\mathrm{D}$ values of the herbaceous species changed with 1 grade only, however, the $\mathrm{K}$ of some species reduced even with 2-3 grades: Carex sylvatica, Chaerophyllum temulum, Festuca gigantea, Milium effusum, Viola reichenbachiana. It is worth noting Campanula latifolia separately as its D decreased from 3 to 1 in one of the relevés. Similarly, the prevalence of Ranunculus ficaria decreased from 4 to 2 in one of the studied areas. In contrast, the D of other species (Allium ursinum, Galeobdolon luteum, Mercurialis perennis, Stachys sylvatica) increased in several quadrates (see the chapter "Ratio of character species") (Table 1).

\section{Plant species composition}

Distribution of constancy classes - In essential, the distribution of constancy classes did not change. A remarkable increase was observed in the number of accidental species (K I) (Fig. 2).

Ratio of character species - In the past three decades, no great changes were detected in the ratio of character species (Table 1). However, it is remarkable that the $\mathrm{Ch}-\mathrm{K}$ and $\mathrm{Ch}-\mathrm{AD}$ of syntaxa related to wet soils (i.e. Galio-Urticetea s. 1., Salicetea purpureae s. 1., Alnetea s. 1., Alnion incanae s. 1.) decreased slight-

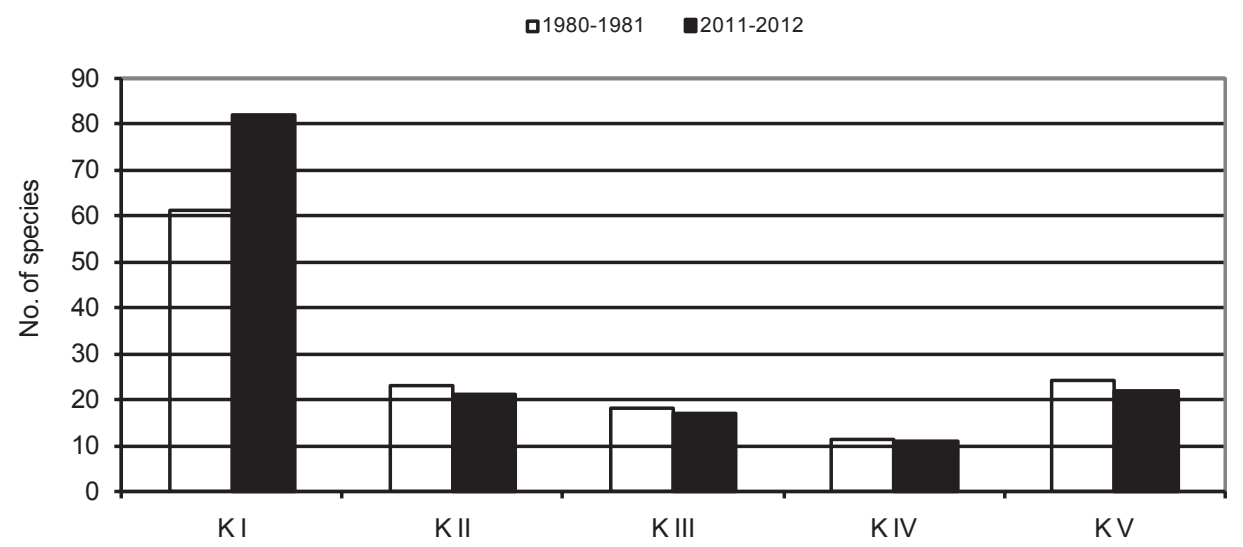

Fig. 2. Distribution of constancy classes 
ly. Similarly, the K of the Alnion incanae-related Viburnum opulus decreased from constant (K V) to subaccessorial (K II) level (Table S2).

Fagetalia species still play dominant role (Table 1). Their Ch-K has slightly decreased; however, interestingly, their Ch-AD has increased. From among the species belonging to this order, the constancy of Carex sylvatica, Festuca gigantea and Viola reichenbachiana has decreased by 2 grades. The most striking, however, is the case with Milium effusum, which proved to be an accessorial species (K III) during the 1980-1981 monitoring, while it did not even turn up in 2011-2012. In turn, the D of some Fagetalia elements has increased: this has happened mainly with Allium ursinum, but the local dominance of Galeobdolon luteum, Mercurialis perennis and Stachys sylvatica has increased strikingly.

The adventive elements have been spreading prominently (Tables S2, 2-3, Figs 3-5): their Ch-K has increased from $8.5 \%$ to $14.9 \%$ and their Ch-AD from $3.0 \%$ to $5.1 \%$. For example, Juglans nigra did not even turn up during the 1980-1981 monitoring, but advanced to be an accidental species (K III), and the constancy of some other species (Celtis occidentalis, Philadelphus coronarius, Phytolacca americana) has increased with 2 grades as well. The D of some adventive woody plants has increased, too: Acer negundo, Celtis occidentalis, Robinia pseudo-acacia. Especially, Acer negundo shows spreading to a serious extent at some places. However, interestingly, its D has remained unchanged at some sample areas.

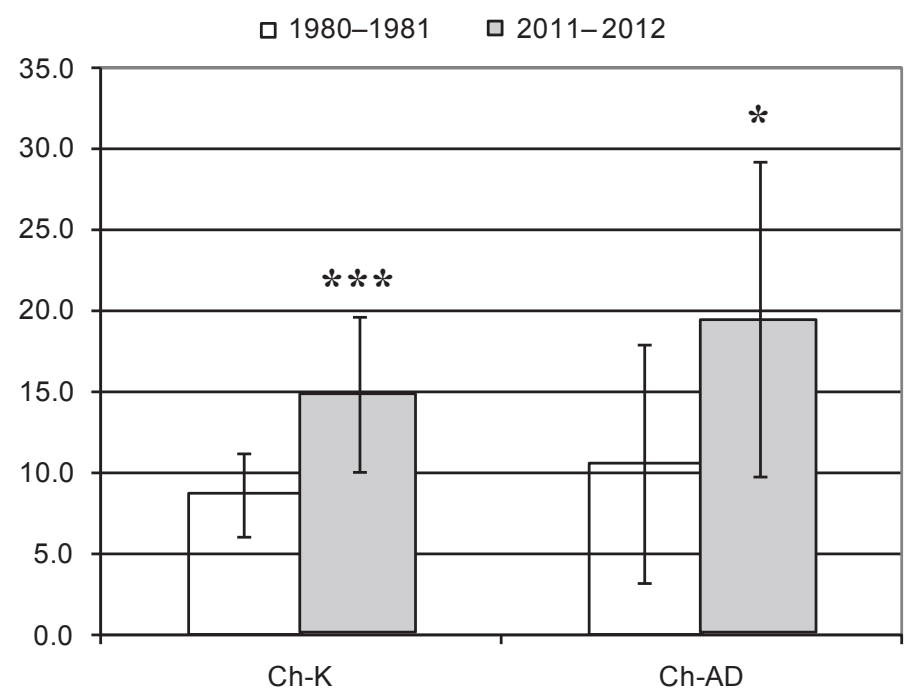

Fig. 3. Ratio of adventive elements (Ch-K = percentage of characteristic species of different syntaxa based on $\mathrm{K} \%$, Ch-AD = percentage of characteristic species of different syntaxa based on A-D\%, ${ }^{* * *}$ and * represent significant differences between 1980-1981 and 20112012 at the 0.001 and 0.05 levels, respectively 


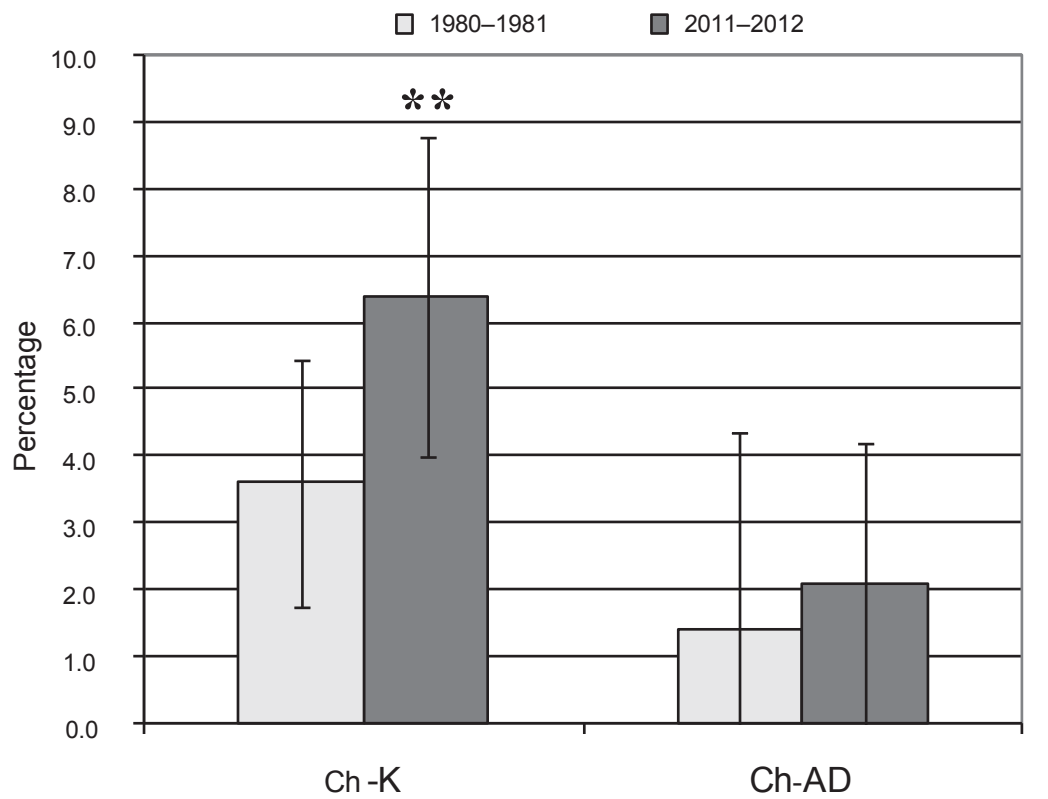

Fig. 4. Ratio of introduced alien species (I) (Ch-K = percentage of characteristic species of different syntaxa based on $\mathrm{K} \%, \mathrm{Ch}-\mathrm{AD}$ = percentage of characteristic species of different syntaxa based on A-D\%, ${ }^{* *}$ represents significant differences between 1980-1981 and 2011-2012 at the 0.01 level

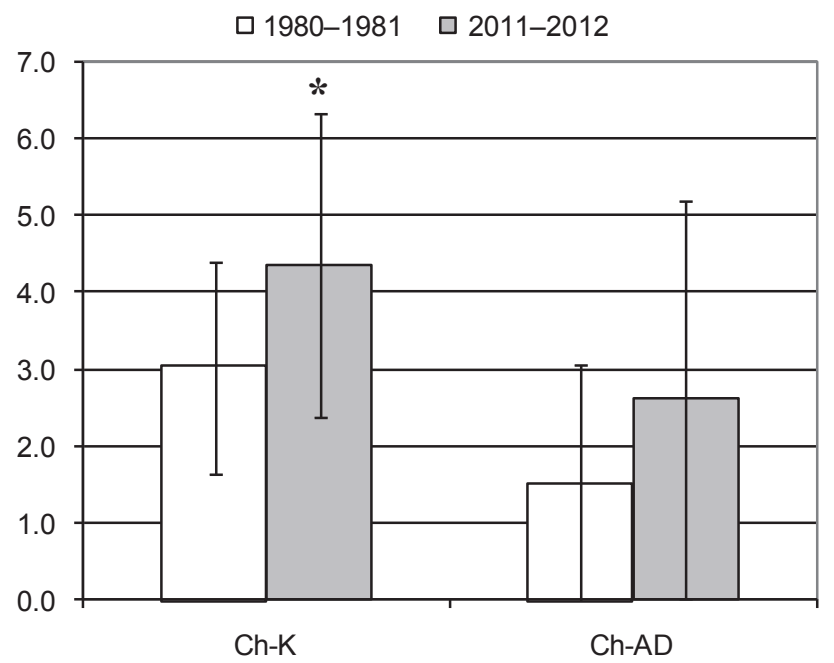

Fig. 5. Ratio of aggressive alien species $(\mathrm{AC})(\mathrm{Ch}-\mathrm{K}=$ percentage of characteristic species of different syntaxa based on $\mathrm{K} \%$, Ch- $\mathrm{AD}$ = percentage of characteristic species of different syntaxa based on A-D\%, * represents significant differences between 1980-1981 and 2011-2012 at the 0.05 level 
Ratio of social behaviour types - The social behaviour types of Borhidi (1993) show similar correspondence to the ratio of character species. Primarily, the increased ratio of the introduced alien species (I) and aggressive alien species (AC) is striking, while the naturalness of these hardwood groves has slightly decreased (Figs 4-5, Table 2).

\section{Results of multivariate statistical analyses}

In order to evaluate the syntaxonomic status of the park's monitored forest groves, we incorporated the semi-natural oak-ash-elm groves of the neighbouring Zámoly Basin and those of Csepel Island into the multivariate analysis as well. Both the dendrogram and scatter plot illustrate that the relevés of the Zámoly Basin are located relatively close to those of Martonvásár, while the material coming from the Csepel Island is more distinct (Figs 6-7).

\section{DISCUSSION}

Questions arising to the naturalness of the manor park

According to the memoir of Therese von Brunswick written in 1846, "nothing but a few trees could have been seen at the eight thousand acres estate" at the beginning of the 1700s, and neither the map of the 2nd military survey of the Austro-Hungarian Empire indicated any forest at the territory of the park (cf. Póka 1978, Kevey 1987). The formation of the semi-natural forest groves happened later, during the construction of the Brunszvik Manor House.

Nevertheless, this does not mean that most of the plants of the manor park came here through introduction. It is known that certain earls would passionately collect the seeds of wild plants and sow them at their estates (cf. Hangay 1889). Therefore, in case of the majority of the plants, it is already impossible to tell, which one got there naturally or by human intervention.

Part of the naturalised plants, however, may have got here naturally. The St László stream offered excellent diaspora route for this purpose. According to the climazonal map of Borhidi (1961), Martonvásár is located at the border of the lowland forest steppe zone. The continental climate impact on the vegetation is compensated by the St László stream. Due to this, the submontane elements (Fagetalia species) could survive here regardless of whether they got here naturally or by human intervention.

According to the results of the analyses (Table S2 and Table 1, Figs 6-7), the current manor park corresponds to a semi-natural oak-ash-elm forest grove. It can be interpreted as a man-made habitat, which further evolved by the ecological succession (in more detail, see Kevey 1987). Thus, the case of 


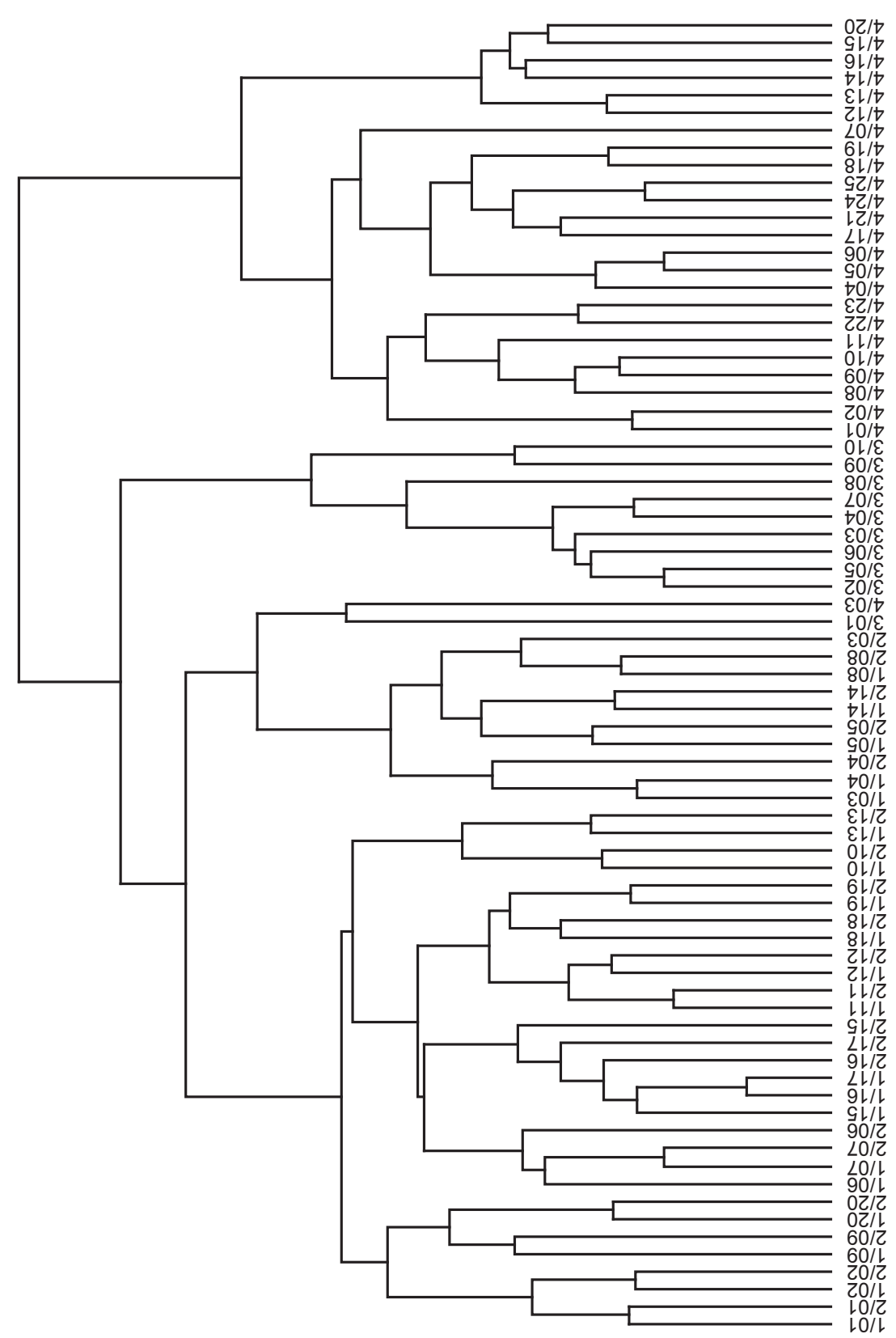

อี ฮิ

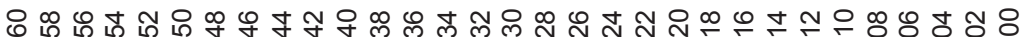
0000000000000000000000000000000 Кł!̣e|!u!ss!̣ 
the Martonvásár Manor Park may be interpreted as an unintentional habitat restoration as well.

\section{Changes in constancy classes}

Regarding the constancy classes, the number of accidental species (K I) has greatly increased (Table S2, Fig. 2). The majority of the newly appeared species are indifferent (e.g. Ballota nigra, Leonurus cardiaca, Plantago major, Poa annua, Solanum nigrum, Sonchus oleraceus, Taraxacum officinale), adventive (e.g. Ambrosia artemisiifolia, Erigeron canadensis, Gleditsia triacanthos, Juglans regia,

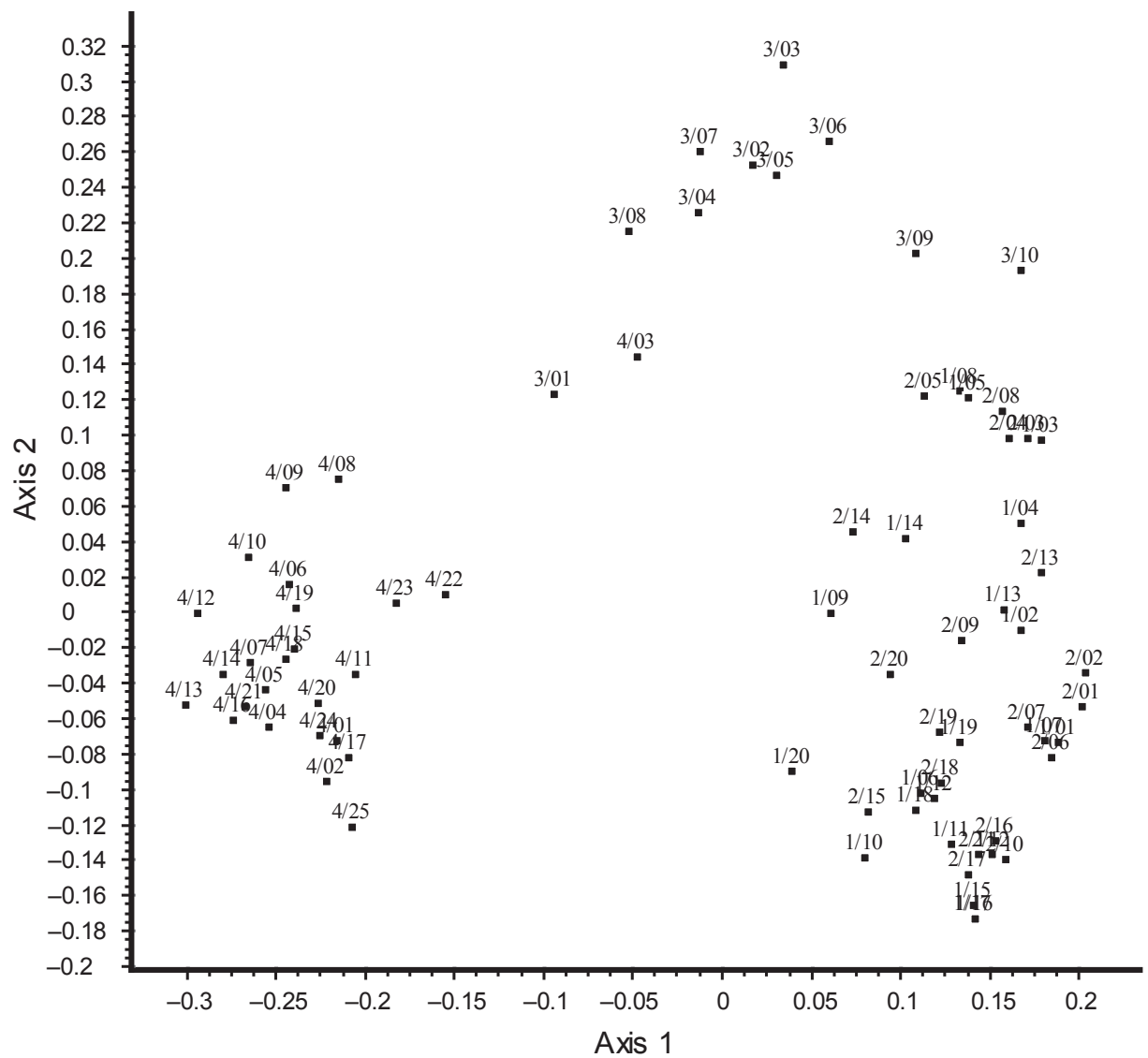

Fig. 7. Similarity of the oak-ash-elm groves relevés of the study on scatter plot illustration (1/1-20: Martonvásár “Manor Park” (Kevey ined.: 1980-1981); 2/1-20: Martonvásár “Manor Park" (Kevey, Majláth, Molnár ined.: 2011-2012), 3/1-10: Zámoly Basin (Kevey ined.); 4/1-25: Csepel Island (Kevey ined.); (method: principal coordinates analysis; coefficient: Baroni-Urbani and Buser)) 
Morus alba, Oxalis fontana, Solidago canadensis) or they were planted as garden plants (e.g. Deutzia scabra, Fritillaria meleagris, Galanthus plicatus, Gymnocladus dioica, Sophora japonica). Although the presence of these plants is not dominant, their appearance denotes degradation to a certain extent. In small number, such plants have also been found that were present in the 1981-1982 relevés, but they were not found during the repeated monitoring. More than one half of these species consist of forest character species (Fagetalia, Alnion incanae, Quercetea pubescentis-petraeae): Adoxa moschatellina, Anemone nemorosa, Campanula rapunculoides, Cornus mas, Dryopteris filix-mas, Impatiens noli-tangere, Malus sylvestris, Melittis melissophyllum, Milium effusum, Viola reichenbachiana, etc. It is striking that Milium effusum, which turned up during the 1981-1982 monitoring as accessorial species (K III), completely lacks from among the species nowadays. We suppose that the only possible explanation for this phenomenon is that it has been superseded during the competition between the species. The absence of these character species also suggests slight degradation.

\section{Changes of the forest dynamics}

From the 1960s, the 20th century's botanical garden style has been prevailing in the park. Today, the characteristics of this period are still reflected by the horticultural rarities, which can be found throughout the whole park. In the 1980s, new approaches appeared in the park management: the former landscape design trend - the formation of a botanical garden, which went against the concept of the English garden style - was replaced by the idea of reconstructing the English garden. Cutting back the characteristics of a dendrological collection, the park management aimed at reconstructing the English garden that features groups of trees and great lawny areas. Károly Örsi's reconstruction plan gave considerable impetus to this trend in 1989. The formation of greater clearings, grove-like structure and the application of mowing (which destroyed the forest undergrowth) did not favour the development of shrub layer of the hardwood grove that already begun to revert into its natural condition. At the frequently visited sites (e.g. the island), the hardwood grove refugia were more heavily affected by the treatment than those at hidden places thus leaving space for spontaneous forest dynamic processes. Therefore, the height and average trunk diameter of these trees have increased continuously in the last 30 years. The upper canopy has grown somewhat thinner at several places as the crowns of the pedunculate oak and narrow-leaved ash (subsp. hungarica) tree, which dominate the upper canopy, rarefies with ageing. Additionally, some old trees fell, too. Today, large trees die from diseases, pest insects or extreme weather. As more light reaches to 
the lower canopy this way, the trees at this level could start growing: both of their height and coverage have increased. This serves as an explanation for the fact that the D of Acer campestre in the lower canopy grew from 2 to 3 in several quadrates. At the beginning of the 1980s the shrubs were cleared at certain parts of the forest (Manninger, ex verb., 1983). Still, the coverage of the shrub layer and the D of certain shrubs continued to grow (e.g. Padus avium, Staphylea pinnata). All this shows the signs of the natural regeneration process of the hardwood groves.

The last 30 years' natural regeneration process was facilitated by the fact that no renewal was attempted. In the period of the study (1981-2011), only one occasion was recorded (in 1992), when renewal of a European beech (Fagus sylvatica) was attempted in the quadrates 6, 7, 10 and 12. Perhaps the planting was inspired by the presence of older beeches in the quadrate 18 . The above-mentioned quadrates lie at the lowest areas, thus they are often covered by inland water in early spring. The wet climate of hardwood groves could ensure favourable conditions for the beeches, however, the high level of water logging has negative effects on them (Gencsi and Vancsura 1992). That is why the renewal attempt - with some exceptions - was not successful.

In several cases, the coverage of the natural saplings (lower shrub layer) and herb layer increased mainly due to the spreading of Hedera helix, Allium ursinum and - at certain places - Galeobdolon luteum. Probably this is the reason why some forest plants disappeared during the last 30 years: e.g. Adoxa moschatellina, Anemone nemorosa, Campanula rapunculoides, Carex sylvatica, Dryopteris filix-mas, Festuca gigantea, Impatiens noli-tangere, Melittis melissophyllum, Milium effusum, Viola reichenbachiana. The case of Campanula latifolia should be mentioned here, too: in one quadrate during the 1980-1981 monitoring, its D was identified as 3 but in 2011-2012 its coverage was already only 1 (Table S2).

\section{Changes in the ratio of character species}

In general, the ratio of character species did not change substantially. The slight aridification implies that the ratio of certain hygrophilous syntaxa (Galio urticetea s. 1., Salicetea purpureae s. 1., Alnetea s. 1., Alnion incanae s. 1.) dropped slightly. Perhaps this is related to the drop from K V to K II in the stability of Alnion incanae-like Viburnum opulus and the decrease from 4 to 2 in the coverage (D) of Ranunculus ficaria. Several Fagetalia character species (e.g. Adoxa moschatellina, Anemone nemorosa, Carex sylvatica, Dryopteris filixmas, Festuca gigantea, Milium effusum, Viola reichenbachiana) disappeared from these hardwood groves. Thus, their $\mathrm{Ch}-\mathrm{K}$ reduced somewhat in 30 years, but their Ch-AD increased slightly mainly due to the spread of Hedera helix, Allium ursinum and - at certain places - Galeobdolon luteum (Table S2). However, 
the spread of adventive species implies degradation. Their $\mathrm{Ch}-\mathrm{K}$ and $\mathrm{Ch}-\mathrm{AD}$ nearly doubled in 30 years (Tables 2-3, Figs 3-5).

The status of the Martonvásár oak-ash-elm groves in the coenotaxonomy

According to the comparison carried out with the neighbouring oak-ashelm groves, the oak-ash-elm groves in the manor park and those in the Zámoly Basin show relatively great similarity. The hardwood groves of the Csepel Island are somewhat different from them (Figs 6-7). Still, in spite of the differences, the groves in Martonvásár can be identified with these neighbouring areas' oak-ash-elm groves. The coenotaxonomic ranking of this association can be represented in the following way.

Division: Querco-Fagea Jakucs 1967

Class: Querco-Fagetea Br.-Bl. et Vlieger in Vlieger 1937 emend. Borhidi in Borhidi et Kevey 1996

Order: Fagetalia sylvaticae Pawłowski in Pawłowski et al. 1928

Group: Alnion incanae Pawłowski in Pawłowski et al. 1928

Subgroup: Ulmenion Oberdorfer 1953

Association: Scillo vindobonensis-Ulmetum Kevey in Borhidi et Kevey 1996

Another, recently published study of the oak-ash-elm groves of Pácin Manor Park (Bodrogköz, Northern Hungary) referred to the Kevey's (1987) relevés. The comparison showed that the groves in Pácin and Martonvásár are relatively similar, however, in Pácin, the ratio of the Fagetalia elements was lower and the number of the indifferent species was higher (Tuba and Szirmai 2008).

\section{Conclusions for nature conservation}

Since 1953, the territory of the Martonvásár Manor Park is a nature reserve area and has national importance. As the last fragments of the oak-ashelm groves of the "Mezőföld" were preserved in its late landowners' manor parks (Martonvásár, Dég, Zólyomi 1967), the hardwood groves in Martonvásár are of great nature conservation significance. This is not to be changed by the fact that the park was created by human intervention, which means that - even if it was not a conscious act - this can be considered as an "unintentional habitat restoration".

Six protected plants were found in the 20 quadrates: Campanula latifolia, Cyclamen purpurascens, Galanthus nivalis, Lonicera caprifolium, Lunaria rediviva, Scilla vindobonensis. Additionally, Fritillaria meleagris and Helleborus dumeto- 
rum are of particular importance from among the species coming from outside of the quadrates. Further natural values of the areas are those Fagetalia species that are typical in our mountains and hilly landscapes but are very rare in the Great Hungarian Plain: Adoxa moschatellina, Allium ursinum, Anemone nemorosa, Corydalis cava, C. pumila, Galeobdolon luteum, Galium odoratum, Geranium phaeum, Mercurialis perennis, Milium effusum, Myosotis sylvatica, Pulmonaria officinalis, etc. Partially, they may be considered as relict species of the once more balanced and humid climate of the palaeobotanical "Bükk 1" phase (cf. Zólyomi 1936, 1952, 1958, Járai-Komlódi 1966, 1968, 1969, 2000).

From the point of view of nature conservation, the spread of invasive species are considered as a problem - their ratio in the past 30 years nearly doubled. There was a comparative analysis in the hardwood floodplain forests of the Slovak and Hungarian datasets over decades carried out by Petrášová et al. (2013). They found a significant increase in the number and cover of recorded neophytes from 1940 until present in both countries. In a broader analysis, time emerged as one of the most significant factors positively affecting the number of neophytes. Beside the species richness of native species, other ecological factors such as the amount of nutrients, light, soil reaction, cover of herb layer and moisture were found important in the spread on the invasive species.

This also explains our present results in the Martonvásár hardwood groves from 1980 to 2012. Factors listed above and have had impact on the spread of invasive species, cover of the herb and shrub layers, local nitrogen accumulation, changes in the ambient light in the forest layers could contributed to the changes in the dominance of invasive plants in Martonvásár.

At this point, it is important to mention the effect of an intense increase in the populations of wild herbivorous mammals. The study area is surrounded by fences thus, limited number of wild animals (mainly deers) can pass through. However, if this happens, its population may overgrow. They are highly harmful since they chew the saplings off of the endemic tree species. They prefer the ash trees but do not spare the saplings of other trees either. According to the observations, they do not harm introduced tree species as much as endemic ones and thus they facilitate their spread. The decline of the stand of Campanula latifolia also can be explained by the chewing of the deers, which made the species unobserved for long time in the area. Since 2007 , measures have been taken to reduce surplus of the wildlife populations, which led to the reappearance of C. latifolia.

In conclusion, the oak-ash-elm grove forests in the Martonvásár Manor Park can be corresponded to those that can be found the neighbouring areas. The results of the 30-year-long study pointed that natural-like regeneration process started in the park (growth of the canopy and shrub level, growth of the coverage, and average trunk diameter). Unfortunately, this process was 
somewhat slowed down by horticultural activities such as the removal of fallen trees, twigs and boughs. Instead of these unnecessary works it would have been more important to take care about the suppression of the invasive trees and herbaceous plants.

Acknowledgements - We wish to express our sincere thanks to those researchers who helped our work: Adolf Olivér Horvát† DSc, István Manninger CSc and Ottó Tukacs horticulturist. We are also grateful to Nóra Timár for her great help in translating our study to English.

\section{REFERENCES}

Ádám, L., Marosi, S. and Szilárd, J. (1959): A Mezőföld természeti földrajza. - Földrajzi Monográfiák II, Akadémiai Kiadó, Budapest, 514 pp.

Becking, R. W. (1957): The Zürich-Montpellier school of phytosociology. - Bot. Review 23: 411-488. http://dx.doi.org/10.1007/bf02872328

Borhidi, A. (1961): Klimadiagramme und klimazonale Karte Ungarns. - Ann. Univ. Sci. Budapest., Sect. Biol. 4: 21-250.

Borhidi, A. (1993): A magyar flóra szociális magatartás típusai, természetességi és relatív ökológiai értékszámai. - Janus Pannonius Tudományegyetem, Pécs.

Borhidi, A. (1995): Social behaviour types, the naturalness and relative ecological indicator values of the higher plants in the Hungarian flora. - Acta Bot. Acad. Sci. Hung. 39: 97-181.

Borhidi, A. and Kevey, B. (1996): An annotated checklist of the Hungarian plant communities II. - In: Borhidi, A. (ed.): Critical revision of the Hungarian plant communities. Janus Pannonius University, Pécs, pp. 95-138.

Borhidi, A., Kevey, B. and Lendvai, G. (2012): Plant communities of Hungary. - Akadémiai Kiadó, Budapest, 544 pp.

Braun-Blanquet, J. (1964): Pflanzensoziologie. Ed. 3. - Springer Verlag, Wien, New York, 865 pp.

Gencsi, L. and Vancsura, R. (1992): Dendrológia. - Mezőgazda Kiadó, Budapest, 728 pp.

Hangay, O. (1889): Erőszakolt flóravidék. - Orvos-Term.tud. Ért. 11: 153-162.

Horváth, F., Dobolyi, Z. K., Morschhauser, T., Lőkös, L., Karas, L. and Szerdahelyi, T. (1995): Flóra adatbázis 1.2. - Vácrátót, 267 pp.

Jakucs, P. (1967): Gedanken zur höheren Systematik der europäischen Laubwälder. - Contrib. Bot. 1967: 159-166.

Jakucs, P. (1973): “Síkfőkút Project". Egy tölgyes ökoszisztéma környezetbiológiai kutatása a bioszféra-program keretén belül. (Environmental-biological research of an oak forest ecosystem within the framework of the biosphere program). - MTA Biol. Oszt. Közl. 16: 11-25.

Járai-Komlódi, M. (1966): Adatok az Alföld negyedkori klíma- és vegetációtörténetéhez I. - Bot. Közlem. 53: 191-201.

Járai-Komlódi, M. (1968): The Late Glazial and Holocene flora of the Hungarian Great Plain. - Ann. Univ. Sci. Budapest. Rolando Eötvös nom., Sect. Biol. 9-10: 199-225.

Járai-Komlódi, M. (1969): Adatok az Alföld negyedkori klíma- és vegetációtörténetéhez II. - Bot. Közlem. 56: 43-55.

Járai-Komlódi, M. (2000): A Kárpát-medence növényzetének kialakulása. - Tilia 9: 5-59. 
Kevey, B. (1979): Az Allium ursinum L. magyarországi elterjedése. - Bot. Közlem. 65: 165175. (1978).

Kevey, B. (1987): A martonvásári kastélypark tölgy-kőris-szil ligeterdői. - Bot. Közlem. 73(1-2): 33-42.

Kevey, B. (2008): Magyarország erdőtársulásai. (Forest associations of Hungary). Die Wälder von Ungarn. - Tilia 14: 1-488.

Kevey, B. and Hirmann, A. (2002): „NS" számítógépes cönológiai programcsomag. - In: Összefoglalók, Aktuális flóra- és vegetációkutatások a Kárpát-medencében V, Pécs, 2002. március 8-10, p. 74.

Király, G. (ed.) (2009): Új magyar füvészkönyv. Magyarország hajtásos növényei. Határozókulcsok. - Aggteleki Nemzeti Park Igazgatóság, Jósvafö, 616 pp.

Manninger, I. (1989): Botanikai érdekességek, hírneves botanikusok Martonvásáron. MTA Mezőgazd. Kut.int. Kísérl. Gazd. Közlem. 89(2): 13-14.

Mucina, L., Grabherr, G. and Wallnöfer, S. (1993): Die Pflanzengesellschaften Österreichs III. Wälder und Gebüsche. - Gustav Fischer, Jena, Stuttgart, New York, 353 pp.

Oberdorfer, E. (1953): Der europäische Auenwald. - Beitr. Naturk. Forsch. Südwestdeutschland 12: 23-70.

Oberdorfer, E. (1992): Süddeutsche Pflanzengesellschaften IV. A. Textband. - Gustav Fischer Verlag, Jena, Stuttgart, New York, 282 pp.

Ormos, I. (1967): A kerttervezés története és gyakorlata. 2. ed. - Mezőgazdasági Kiadó, Budapest, $523 \mathrm{pp}$.

Pawłowski, B., Sokołowski, M. and Wallisch, K. (1928): Die Pflanzenassoziationen des Tatra-Gebirges VII. Die Pflanzenassoziationen und die Flora des Morskie Oko-Tales. - Bull. Int. Acad. Polon. Sci. Lettr., Cl. Sci. Math. Nat.; Sér. B: Sci. Nat. (Suppl.) 1927: 205-272.

Petrášová, M., Jarolimek, I. and Medvecka, J. (2013): Neophytes in Pannonian hardwood floodplain forests: history, present situation and trends. - Forest Ecol. Manag. 308: 31-39. http://dx.doi.org/10.1016/j.foreco.2013.07.041

Podani, J. (2001): Syn-Tax 2000 Computer programs for data analysis in ecology and systematics. - Scientia, Budapest, 53 pp.

Póka, M. (1978): A Martonvásári Park. - Búvár 33: 377.

QGIS (2014): QGIS Geographic Information System. Open source geospatial foundation project. http://qgis.osgeo.org

Soó, R. (1964, 1966, 1968, 1970, 1973, 1980): A magyar flóra és vegetáció rendszertani-növényföldrajzi kézikönyve, I-VI. - Akadémiai Kiadó, Budapest.

Tuba, Z. and Szirmai, O. (2008): A pácini kastélyparkot övező ártéri erdő botanikai jellemzése és jelentösége. - In: Tuba, Z. and Frisnyák, S. (eds): Bodrogköz. A magyarországi Bodrogköz tájmonográfiája. Lorántffy Alapítvány, Gödöllő-Sárospatak, pp. 633-640.

Vlieger, J. (1937): Aperçu sur les unités phytosociologiques supérieures des Pays-Bas. Nederlandsh Kruidkundig Archief 47: 335.

Zádor, A. (1973): Az angolkert Magyarországon. - Épités - Építészettudomány 5(1-2): 3-53.

Zólyomi, B. (1936): Tízezer év története virágporszemekben. - Term.tud. Közl. 68: 504-516.

Zólyomi, B. (1952): Magyarország növénytakarójának fejlődéstörténete az utolsó jégkorszaktól. - MTA Biol. Oszt. Közlem. 1: 491-530.

Zólyomi, B. (1958): Budapest és környékének természetes növénytakarója. - In: Pécsi, M. (ed.): Budapest természeti képe. Akadémiai Kiadó, Budapest, pp. 511-642.

Zólyomi, B. (1967): Természetes növényzet. - In: Pécsi, M. (ed.): Magyarország tájföldrajza 1. A dunai Alföld. Akadémiai Kiadó, Budapest, pp. 285-288. 


\title{
ELECTRONIC SUPPLEMENTS
}

\author{
Table S1
}

Geocoordinates and size of the quadrates

Table S2

Phytocoenological table of Scillo vindobonensis-Ulmetum

(A1 = upper canopy, $\mathrm{A} 2=$ lower canopy, $\mathrm{Agi}=\mathrm{Alnenion}$ glutinosae-incanae, $\mathrm{Ai}=\mathrm{Alnion}$ incanae, $\mathrm{Apa}=$ Abieti-Piceea, $\mathrm{AQ}=$ Aceri tatarici-Quercion, $\mathrm{AR}=$ Agropyro-Rumicion crispi, $\mathrm{Ar}=$ Artemisietea, Ara = Arrhenatheretea, Ate = Alnetea glutinosae, B1 = shrub layer, B2 = lower shrub layer (saplings), Bia = Bidentetea, $\mathrm{C}=$ herb layer, $\mathrm{Cal}=$ Calystegion sepium, Che $=$ Chenopodietea, $\mathrm{ChS}=$ Chenopodio-Scleranthea, $\mathrm{Cp}=$ Carpinenion betuli, $\mathrm{D}=$ dominance classes on a discrete scale of 1-5, Epa = Epilobietea angustifolii, EuF = Eu-Fagenion, ex verb. $=$ ex verbis (oral statement), $\mathrm{F}=$ Fagetalia sylvaticae, $\mathrm{FBt}=$ Festuco-Brometea, $\mathrm{FPi}=$ Festuco-Puccinellietalia, GA = Galio-Alliarion, ined. = ineditum (inedited), $\mathrm{K}=$ constancy classes on a discrete scale of $\mathrm{I}-\mathrm{V}$, Mag = Magnocaricetalia, MoA = Molinio-Arrhenatherea, $\mathrm{MoJ}=$ Molinio-Juncetea, $\mathrm{OCn}=$ Orno-Cotinion, $\mathrm{Pla}=$ Plantaginetea, $\mathrm{Pna}=$ Populenion nigro-albae, $\mathrm{Pol}=$ Polygonion avicularis, $\mathrm{PQ}=$ Pino-Quercetalia, $\operatorname{Prf}=$ Prunion fruticosae, Pru $=$ Prunetalia spinosae, Pte $=$ Phragmitetea, $Q c=$ Quercetalia cerridis, $Q f a=$ Quercion farnetto, QFt = Querco-Fagetea, Qpp = Quercetea pubescentis-petraeae, Qr = Quercetalia roboris, Qrp = Quercion robori-petraeae, $S=$ summa (sum), Sal = Salicion albae, Sea = Secalietea, $\mathrm{s} .1 .=$ sensu lato, $\mathrm{Spu}=$ Salicetea purpureae, $\mathrm{TA}=$ Tilio platyphyllae-Acerenion pseudoplatani, Ulm = Ulmenion, US = Urtico-Sambucetea, VP = Vaccinio-Piceetea)

\section{Table S3}

Data of the relevés.

(1) 1980-1981: Bedrock: 1-20: loess; Soil: 1-20: Fluvisol (brown lowland soil); Recorded by: 1-20: Kevey (ined.), (2) 2011-2012: Bedrock: 1-20: loess; Soil: 1-20: Fluvisol (brown lowland soil); Recorded by: 1-20: Kevey, Majláth, Molnár (ined.) 